\title{
Diskresi Hakim dalam Memutus Perkara Cerai Talak melalui Video Call pada Saat Pandemi Covid-19
}

\author{
Annisa Sherin Millenia*, Maman Abdurrahman \\ Prodi Hukum Keluarga Islam, Fukultas Syariah Universitas Islam Bandung \\ Bandung, Indonesia. \\ *Annisasherin21@gmail.com, mamanabdurrahman@unisba.ac.id
}

\begin{abstract}
Research in this thesis is a type of descriptive research. The data used in this study is secondary data with primary legal material in the form of Al-Qur'anul Karim, Compilation of Islamic Law, Law No. 1 of 1974, Law No. 48 of 2009 on the Power of Justice. While the approach the author uses is juridical normative. The author uses data collection techniques or library research in accordance with PERMA No. 1 Year 2019 on The Administration of Cases and Hearings in the Court conducted electronically, however, the facts that occurred, the absence of the respondent at the court on the grounds that the existence of PSBB, although the call has been made officially and appropriately. In the examination of the Respondent from the attorney general the applicant submits an application to the panel of judges to continue the trial and examine the respondent via video call. The results of this study showed that the discretion of the Judge in deciding the divorce lawsuit through a video call in the Brass Religious Court, the judge prioritized the principle of justice and efficacy for the community, especially to the litigants.
\end{abstract}

Keywords: Discretion, Divorce Talak, Video Call, Covid-19.

\begin{abstract}
Abstrak. Penelitian dalam skripsi ini merupakan jenis penelitian deskriptif. Data yang digunakan dalam penelitian ini adalah data sekunder dengan bahan hukum primer berupa Al-Qur'anul Karim, Kompilasi Hukum Islam, Undang-undang No. 1 Tahun 1974, Undang-Undang No. 48 Tahun 2009 tentang Kekuasaan Kehakiman. Sementara pendekatan yang penulis gunakan adalah yuridis normatif. Penulis menggunakan teknik pengumpulan data atau library research sesuai dengan PERMA No. 1 Tahun 2019 tentang Adminsitrasi Perkara dan Persidangan di Pengadilan dilakukan secara elektronik. Namun, Fakta yang terjadi, ketidakhadiran dari termohon di persidangan dengan alasan saat itu adanya PSBB, meskipun telah dilakukan panggilan secara resmi dan patut. Dalam pemeriksaan termohon dari kuasa hukum pemohon mengajukan permohonan kepada majelis hakim untuk tetap melanjutkan persidangan dan memeriksa pihak termohon melalui video call. Hasil penelitian ini menunjukkan bahwa diskresi Hakim dalam memutus perkara gugatan cerai talak melalui video call di Pengadilan Agama Kuningan, hakim mengutamakan asas keadilan dan kemanfatan bagi masyarakat, khususnya kepada pihak yang berperkara.
\end{abstract}

Kata Kunci: Diskresi, Cerai Talak, Video Call, Covid-19. 


\section{A. Pendahuluan}

Perceraian di masyarakat saat ini sudah banyak terjadi, termasuk di daerah Kuningan. Dalam islam, perceraian diatur dengan sedemikian rupa. Saat ini perceraian terdapat dua kejadian, yaitu; perceraian secara resmi melalui pengadilan, dan perceraian tidak melalui pengadilan. Fakta di lapangan bahwasanya terjadi perceraian cerai talak, dalam persidangan kedua di Pengadilan Agama Kuningan, perkara Nomor 991/Pdt.G/2020/PA.Kng yang tidak dihadiri oleh Termohon selama tiga kali persidangan. Namun, fakta tersebut tidak diputuskan gugur. Mengenai kapan suatu putusan gugur dapat dijatuhkan, MA telah memberikan petunjuk bahwa apabila sidang pertama penggugat tidak datang, meskipun ia telah dipanggil dengan patut, dan juga tidak mengirim kuasanya, sementara tergugat atau kuasanya yang sah datang, gugatan digugurkan dan penggugat dihukum untuk membayar biaya perkara.

Dalam mengajukan gugatan itu merupakan kepentingan hukum dari penggugat. Maka seharusnya penggugat hadir pada sidang yang telah ditetapkan. Atas ketidakhadiran penggugat pada hari yang telah ditentukan, dengan begitu penjatuhan putusan gugur ditujukan kepada kepentingan hukum tergugat untuk memberikan rasa keadilan bagi tergugat, karena tergugat sudah mengorbankan waktu, tenaga dan uang. Perceraian hanya dapat dilakukan oleh hakim di depan sidang Pengadilan Agama setelah Pengadilan Agama tersebut berusaha dan tidak berhasil mendamaikan kedua belah pihak (Pasal $115 \mathrm{KHI}$ ). Di Indonesia, lembaga peradilan menurut UUD 1945 diselenggarakan oleh Kekuasaan Kehakiman, sebagaimana yang sudah diatur dalam UU RI NO. 48 Tahun 2009. Di Pengadilan Agama Kuningan pada saat pandemi Covid-19 beberapa kali kuasa hukum pemohon tidak dapat menghadirkan pemohon di persidangan sampai dengan kesempatan ketiga kali.

Permohonan cerai talak yang telah didaftar sebagai perkara, oleh hakim akan diterima dan diputus dengan membuat penetapan yang mengabulkan atau menolak permohonan tersebut. Aktifitas yang dilakukan oleh hakim untuk mengabulkan permohonan merupakan sebuah diskresi (kebijaksanaan). Sedangkan, di dalam hukum acara perdata tidak diatur terkait dengan pemeriksaan pemohon melalui video call di persidangan.

\section{B. Landasan Teori}

Diskresi berasal dari bahasa Belanda yang artinya kebijaksanaan, diskresi dalam bahasa Inggris) secara bahasa adalah freedom or authority to make dicisions and choises power to judge or act. Alvina Treut Burrows (ed) menyatakan discreation: ability to choose wisely or to jugde one self (kemampuan untuk memilih secara bijaksana atau mempertimbangkan bagi diri sendiri, memutuskan sesuatu tidak berdasarkan ketentuan-ketentuan peraturan, UndangUndang atau hukum yang berlaku, tetapi atas dasar kebijaksanaan, pertimbangan, atau keadilan yang berkaitan dengan membuat keputusan yang tidak ketat diatur dalam kaidah hukum melainkan atas unsur penilaian pribadi. Diskresi menurut Kamus Besar Bahasa Indonesia (KBBI) diartikan sebagai kebebasan mengambil keputusan sendiri disetiap situasi yang dihadapi. Sedangkan menurut kamus hukum berarti kebebasan mengambil keputusan dalam setiap situasi yang dihadapi menurut pendapatnya sendiri. Seperti yang telah disebutkan diatas, terkait dengan definisi dari diskresi maka dapat difahami bahwa diskresi hakim ialah kewenangan yang dimiliki oleh hakim untuk memutuskan suatu perkara atas dasar inisiatif sendiri. pada Pasal 22 ayat 2 UU No. 30 Tahun 2014 tentang Administrasi Pemerintahan, disebutkan bahwa setiap penggunaan Diskresi Pejabat Pemerintahan bertujuan untuk:

1. Melancarkan penyelenggaraan pemerintahan;

2. Mengisi kekosongan hukum;

3. Memberikan kepastian hukum; dan

4. Mengatasi stagnasi pemerintahan dalam keadaan tertentu guna kemanfaatan dan kepentingan umum

Hal-hal penting yang berkaitan tentang diskresi diatur dalam Undang-Undang Nomor 30 Tahun 2014 tentang Administrasi Pemerintahan. Diantaranya Pasal 1 angka 9, Pasal 6 ayat (2) huruf e jo ayat (1), Pasal 1 angka 3. Praktek diskresi ini berkembang pada sistem hukum Common Law yang menganut aliran Realisme hukum. Aliran Realisme hukum dapat dikenal 
sebagai konsep yang radikal tentang proses peradilan. Aliran realism menyatakan bahwa hakim tidak hanya menentukan hukum, akan tetapi hakim juga dapat membentuk hukum. Hakim harus memilih, menentukan prinsip-prinsip yang akan dipakai dan pihak yang dimenangkan. Dalam keputusannya, hakim sering mendahului penggunaan prinsip-prinsip hukum yang formal. Keputusan pengadilan selalu dapat dikembangkan untuk dapat menunjang perkembangan atau hasil dari proses hukum. Keputusan pengadilan dibuat berdasarkan konsepsi-konsepsi hakim yang berkaitan dengan keadilan dan dirasionalisasikan dalam pendapat tertulis. Ahli-ahli hukum dari aliran ini menaruh perhatian yang sangat besar tentang keadilan walaupun mereka berpendapat secara ilmiah tidak dapat ditentukan apa yang dinamakan hukum yang adil.

Di Indonesia, ada sebagian hakim yang menggunakan keputusan sendiri, hukum adat, maupun yurisprudensi sebagai dasar keputusannya. Hal tersebut mengingat undang-undang Ketentuan Pokok Kekuasaan Kehakiman no 35 tahun 1999 perubahan dari undang-undang no 14 tahun 1970 menyatakan bahwa hakim dan juga semua penegak hukum dan keadilan wajib menggali, mengikuti dan memahami nilai yang hidup dalam masyarakat. Hal tersebut dapat memberi peluang kepada hakim di Indonesia untuk memperbaiki citra yang kurang baik terhadap hukum bagi sistem yang berkembang di Indonesia.

Tata cara atau prosedur penggunaan diskresi sangat penting, karena dalam pengambilan suatu diskresi diperlukan ketelitian Pejabat Pemerintahan dalam pelaksanaannya. Apabila suatu prosedur tersebut tidak dilakukan secara tepat, maka terdapat konsekuensinya, seperti dalam Pasal 25 menyebutkan tentang prosedur terkait tindakan diskresi.

Landasan hukum diskresi Hakim adalah pelaksana kekuasaan kehakiman yang merdeka, seperti pada pasal 24 UUD 1945 jo. Pasal 21 UU No. 4 tahun 2004. Tujuan diskresi tertuang dalan Pasal 22 ayat (2) Undang-Undang Republik Indonesia Nomor 30 Tahun 2014 tentang Administrasi Pemerintahan yang menyebutkan bahwa setiap penggunaan diskresi bertujuan untuk melancarkan penyelenggaraan pemerintahan, mengisi kekosongan hukum, dan mengatasi stagnasi pemerintahan dalam keadaan tertentu guna kemanfaatan dan kepentingan umum.

\section{Hasil Penelitian dan Pembahasan}

Pandemi saat ini mengakibatkan keterbatasan yag sangat berpengaruh bagi penyelesaian perkara adapun penggunaan pendekatan kaidah hukum Islam di Pengadilan Agama memiliki dasar hukum yang kuat. Dalam Undang-Undang Kekuasaan Kehakiman, Hakim sebagai penegak hukum dan keadilan wajib menggali, mengikuti dan memahami nilai-nilai hukum yang hidup di masyarakat. Hakim sebagai perumus dan penggali dari nilai-nilai hukum yang hidup di masyarakat untuk mengenal, merasakan, dan mampu menyelami perasaan hukum dan rasa keadilan yang hidup dalam masyarakat. Dengan demikian, Hakim dapat memberikan putusan yang sesuai dengan hukum dan rasa keadilan masyarakat.

Dalam melakukan ijtihad hakim agama di Indonesia menggunakan metode yang dinamakan ushul fiqh. Dalam ushul fiqh dirumuskan metode untuk memahami hukum Islam dan memahami dalil-dalil hukum. Dengan dalil-dalil tersebut dapat dibangun hukum Islam yang ketentuan hukumnya sesuai dengan akal sehat (a reasonable assumtion) pertimbangan hukum dari majelis hakim di pengadilan agama. Hasil kajian dari beberapa ketetapan pengadilan agama menunjukkan bahwa dalam pertimbangan majelis hakim cenderung masih menggunakan hukum, menyesuaikan dengan teori tujuan penetapan hukum dalam metodologi hukum Islam atau teori maqashid al-ahkam sebagaimana yang telah diuraikan oleh al Imam Muhammad Abu Zahra bahwa penetapan hukum Islam diarahkan pada tiga tujuan.

Terdapat banyak dampak dari adanya pandemi Covid-19 salah satunya adalah Pengadilan Agama yang berpengaruh kepada proses penanganan perkara di Pengadilan Agama yang berakibat penundaan persidangan, dan ditiadakan layanan pendaftaran secara manual, dan hanya menerima pendaftaran secara E-Court.

Mulai tahun 2019, dengan dikeluarkannya PERMA No. 1 Tahun 2019 tentang Adminsitrasi Perkara dan Persidangan di Pengadilan secara Elektronik, Mahkamah Agung RI 
memperkenalkan cara baru persidangan yaitu persidangan secara online atau persidangan yang dilakukan secara elektronik (E-Litigation).

Ketentuan dalam tatacara mengakses E-Court dapat memberikan kemudahan kepada masyarakat dalam mengurus perkaranya di Pengadilan karena sesuai dengan konsideran PERMA NO. 1 Tahun 2019 yaitu mewujudkan peradilan yang efektif dan efisien. Informasi yang didapatkan oleh penulis, bahwa di Pengadilan Agama Kuningan akan memeriksa Termohon tanpa kehadiranya dipersidangan, sehingga persidangan ditunda untuk memanggil kembali pihak yang bersangkutan agar menghadiri persidangan. Tetap saja persidangan berikutnya yang bersangkutan tidak hadir, maka akan diperiksa melalui video call oleh Majelis Hakim.

Kehadiran pihak berperkara secara fisik di pengadilan merupakan hal yang utama dan penting, karena apabila penggugat tidak hadir dalam persidangan maka perkara yang diajukan dapat gugur, sedangkan jika tergugat tidak hadir maka dapat berakibat perkara diputus secara verstek. Hakim menjatuhi putusan verstek, dengan syarat bahwa tergugat tidak hadir pada persidangan pertama tanpa alasan yang sah meskipun telah dipanggil secara patut, sedangkan penggugat hadir.

Pelaksanaan E-Litigasi merupakan alternatif utama dalam penyelesaian perkara di Pengadilan Agama di masa pandemi. Dalam lembaga peradilan memiliki upaya untuk mencegah dan memutus potensi penyebaran Covid-19 dengan memulai mempraktikkan sidang secara online (E-Litigasi).

Dalam Pengadilan Agama Kuningan belum sepenuhnya menerapkan pelaksanaan ELitigasi ketika persidangan berlangsung. Sebagaimana yang diketahui bahwa ruang lingkup penyelesaian perkara di Pengadilan Agama adalah gugatan perdata, sebagai contoh gugatan cerai talak di Pengadilan Agama Kuningan. Meskipun dalam penerapannya ada beberapa perkara yang ditangani melalui jalur E-Litigasi, tetapi tidak selamanya menggunakan jalur tersebut dalam setiap proses persidangan yang berlangsung.

Seperti yang diketahui bahwa kewenangan Hakim yang besar itu menuntut tanggung jawab, hakim termasuk dalam sistem tata hukum di Indonesia yang berkedudukan sebagai pejabat pelaku kekuasaan kehakiman. Maksud dari kedudukan tersebut bahwa Hakim merupakan Pejabat Peradilan yang diberi wewenang undang-undang untuk mengadili. Terdapat beberapa kemungkinan atau pengunduran dengan permohonan menunda sidang atau permohonan, perpanjangan, penundaan sidang yang dimohon oleh satu pihak dengan alasan bukti-bukti belum lengkap sehingga dibutuhkan waktu untuk melengkapinya, atau yang lainnya. Namun, dalam permohonan pengunduran tidak mengikat hakim sehingga hakim bebas mengabulkan atau menolak pengunduran putusan.

Sebagaimana pada gugatan perkara cerai talak di Pengadilan Agama Kuningan, Hakim menunda sidang dikarenakan persidangan yang tidak dihadiri Termohon, dengan begitu Hakim mengajukan juru sita untuk memanggil pihak Termohon untuk hadir di persidangan selanjutnya. Namun yang menjadi hambatan ketika sidang kedua, Termohon tetap tidak hadir di persidangan karena sedang berada di luar kota saat PSBB berlangsung. Sehubungan dengan hal tersebut, maka Hakim memberikan pertimbangannya di dalam proses persidangan berlangsung. Untuk mengatasi hambatan di dalam proses persidangan yang berlangsung, maka Hakim melakukan pertimbangan atas berbagai alasan untuk menyelesaikan suatu perkara.

Hakim ketua melakukan musyawarah yang didasari pertimbangan dengan hakim anggota untuk melakukan pemeriksaan kepada Termohon melalui video call. Adanya Pertimbangan Hakim tersebut, maka menjadikan proses persidangan tetap berlanjut walaupun tidak dihadiri secara fisik oleh Termohon dalam perkara gugatan cerai talak satu raj' $i$ di Pengadilan Agama Kuningan. Pertimbangan hakim dapat dikatakan/ dengan kata lain yaitu diskresi hakim merupakan persoalan yang penting dalam kelanjutan proses perkara, hakim dalam mengambil putusan sendiri dengan situasi yang dihadapi. Sama halnya dengan ketidak hadiran salah satu pihak di dalam persidangan berlangsung, dan Hakim melakukan kebijaksanaan untuk mengambil keputusan sendiri. 


\section{Kesimpulan}

Sebagaimana dikeluarkannya PERMA No. 1 Tahun 2019 tentang Adminsitrasi Perkara dan Persidangan di Pengadilan secara Elektronik, Mahkamah Agung RI memperkenalkan cara baru persidangan yaitu persidangan secara online atau persidangan yang dilakukan secara elektronik (E-Litigation). Meskipun demikian, aturan ini tidak sepenuhnya diterapkan dalam penanganan perkara di Pengadilan Agama Kuningan. Sebagaimana dalam gugatan cerai talak Nomor 991/Pdt.G/2020/PA.Kng pemeriksaan Termohon dilakukan secara daring atau melalui video call. Dalam memproses perkara pada saat pandemi Covid-19 ketika mengadili maupun memproses cerai talak Hakim ketika melakukan putusan dalam perkara tidak langsung memberikan keputusan secara sepihak, melainkan Hakim memiliki dasar atau pertimbangannya untuk memutus suatu perkara dalam persidangan. Dalam Hukum Acara Perdata maupun dalam Praktik peradilan di Pengadilan Agama belum diatur secara khusus dan jelas mengenai pemeriksaan pihak yang berhalangan hadir di persidangan dapat disampingi melalui video call. Sehingga majelis hakim bertindak dan memutus atas inisiatif sendiri, dengan melakukan diskresinya untuk mengabulkan permohonan kuasa hukum agar pemeriksaan tetap berjalan meskipun melalui daring. Pada intinya, tetap saja majelis hakim memperhatikan rasa keadilan, dan kemanfaatan bagi masyarakat.

\section{Daftar Pustaka}

[1] Amin Fauzi, thesis, IAIN Walisongo, hlm.75. " Relevansi Teori Ushul Fiqh Kontemporer Bagi Pengembangan Ijtihad Hakim Agama di Indonesia." Thesis IAIN Walisongo, n.d.: 75.

[2] Anshori, Lutfil. "Diskresi dan Pertanggungjawaban Pemerintah Dalam Penyelenggaraan Pemerintahan." Jurnal Yuridis, 2015: 136.

[3] Pemohon, Kuasa Hukum, wawancara oleh Annisa Sherin. Fakta Lapangan Diskresi Hakim di Pengadilan Agama Kuningan (5 September 2020).

[4] Pasal 25 Undang-Undang Nomor 30 Tahun 2014 tentang Administrasi Pemerintahan, pdf

[5] Pasal 22 ayat 2 Undang-Undang Nomor 30 Tahun 2014 tentang Administrasi Pemerintahan 